\title{
Partisipasi Masyarakat dalam Pembentukan Undang-undang ${ }^{1}$
}

\author{
Saifudin
}

\begin{abstract}
It is not something strange to find that a constitution of law validated in the society is rejected by any element of society in implementing it because the material content is unmatched with societal interest and it is far from the societal justice, even it tends to elitist. Therefore, it need to think on the process of societal participation in creating the constitution on laws.
\end{abstract}

\section{Pendahuluan}

Pembentukan undang-undang merupakan individu-individu manusia dengan segala bagian dari aktivitas dalam mengatur dimensinya ${ }_{1}{ }^{3}$ sehingga merancang dan masyarakat ${ }^{2}$ yang merupakan gabungan dari membentuk undang-undang adalah merupakan

'Tulisan inipemah disampaikan dalam "Diskusi Terbatas dalam Rangka Pengembangan Badan Legislasi" kejjasama Badan Legislasi DPR RI, UNDP, dengan Fakultas Hukum Universitas Islam Indonesia, yang diselenggarakan pada tanggal 27-28 Juni 2002 di Hotel Santika Yogyakarta.

2Satjipto Rahardjo, "Penyusunan Undang-undang yang Demokratis," makalah seminar. Mencari Model Ideal Penyusunan Undang-undang yang Demokratis dalam Konggres Asosiasi Sosiologi Hukum Indonesia, Fakultas Hukum, Undip, Semarang, tanggal 15 - 16 April 1998, hlm. 3. Sementara itu bertalian dengan "masyarakat" dapat dipahami sebagai "any association of human being" yaitu berbagai pengelompokan tentang kehidupan manusia, yang secara umum dapat berujud dalam tiga hal yaitu: pertama, pengelompokan keluarga tempat manusia lahir dan dibesarkan; kedua, pengelompokan di mana seseorang dipaksa untuk berkompetisi guna mendapatkan keuntungan sosial dan ekonomi seperti serikat-serikat dagang atau kelompok-kelompok profesional; dan ketiga, pengelompokan sukarela (voluntary) seperti kelompok-kelompok keagamaan. Tiga pengelompokan masyarakat tersebut berada dalam wadah yang dinamakan negara, dan dengan demikian maka negara dilihat dari perspektif politik adalah "a society politically organised". Lihat C.F. Strong dalam Political Modern Constitution, Edition First, (London: E.L.B.S. Published, 1966), hlm. 4.

${ }^{3}$ Dimensi-dimensi manusia yang harus diperhatikan dalam pembentukan undang-undang adalah bahwa manusia itu adalah makhluk mono-dualis jiwa-raga, mono-dualis individu-sosial, mono-dualis pribadi mandirimakhluk Tuhan. Lihat Damarojati Supadjar, "Mencari Model Penyusunan Undang-undang yang Demokratis," 
suatu pekerjaan yang sulit.. ${ }^{4}$ Kesulitan ini terletak pada kenyataan bahwa kegiatan pembentukan undang-undang adalah suatu bentuk komunikasi antara lembaga yang menetapkan yaitu pemegang kekuasaan legislatif dengan pembacanya yaitu rakyat dalam suatu negara. ${ }^{5}$ Dalam proses pembentukan undang-undang ini, di dalamnya terdapat transformasi visi, misi dan nilai yang. diinginkan oleh lembaga pembentuk undangundang dengan masyarakat dalam suatu bentuk aturan hukum. Dengan demikian, sejak proses perancangan telah dituntut agar perundang-undangan yang dihasilkan mampu memenuhi berbagai kebutuhan sebagai berikut: pertama, mampu untuk dilaksanakan; kedua, mampu untuk ditegakkan, efektif, efisien, konsisten; dan ketiga, sesuai dengan prinsipprinsip jaminan hukum dan persamaan hakhak sasaran yang diatur. ${ }^{6}$ Selain berbagai kesulitan tersebut, pembentuk undang-undang berpacu dengan dinamika perkembangan masyarakat yang terus berubah sejalan dengan nilai-nilai yang dianggap baik oleh masyarakat. Dengan kata lain, pembentukan undang-undang sebagai bagian dari proses pembentukan sistem hukum yang lebih luas tidaklah statis, tetapi mengalami dinamika perubahan. ${ }^{7}$

Sebagai negara yang sedang berkembang, Indonesia telah lama merasakan kesulitan dalam pembentukan undang-undang. Kesulitan ini lebih dirasakan oleh bangsa Indonesia, karena sekarang negara tengah menghadapi problem sosial secara mendasar pada permasalahan struktural dan kultural yang mult dimensi. ${ }^{8}$ Padahal pembentukan undangundang ini - sekarang dan di masa yang akan datang - akan terus mengalami peningkatan sebagai respon atas tuntutan masyarakat seiring dengan bertambah kompleksnya perkembangan dan kondisi masyarakat. ${ }^{9}$

makalah dalam seminar Mencari Model Ideal Penyusunan Undang-undangyang Demokratis dalam Konggres Asosiasi Sosiologi Hukum Indonesia, Fakultas Hukum, Undip, Semarang, tanggal 15-16 April 1998, hlm. 4-5.

"Irawan Soejito, Teknik Membuat Undang-undang, Cetakan Kelima, (Jakarta: Pradnya Paramita, 1993), him. 3.

'Pierre Andre Cote, The Interpretation of Legislation in Canada, 2ndEdition, (Quebeec: Les Editions Yvon Balais, Inc., 1991), him. 4

'Joumal Volume 9, Issue 2, Start Page 149 - 159, ISSN 13600834, "Legislative Technique as Basis of a Legislative Drafting System Information \& Communications Technology Law,"Abindon, Jun 2000, hlm. 2.

'Laurence M. Friedman, The Legal System, A Social Science Perspective (New York: Rusel Sage Foundation, 1975), hlm. 269. Lihat pula Fiona Patfield and Robin White, The Changing Law (London and New York: Liecester University Press, Liecester, 1990), hlm. I.

${ }^{8}$ Permasalahan struktural adalah permasalahan yang timbul dalam hidup bermasyarakat, berbangsa dan bemegara yang disebabkan oleh keberadaan tatanan strukturorganisasi ketatanegaraan dalam penyelenggaraan pemerintahan, baik menyangkut kewenangan, tugas maupun penerapan dari kewenangan yang dimilikinya. Sedangkan permasalahan kultural adalah permasalahan yang ditimbulkan dari kondisi sosial masyarakat, baik yang berupa kemiskinan yang tinggi, pendidikan yang rendah maupun kesadaran hukum yang rendah pula.

${ }^{9} \mathrm{~K}$ ebutuhan akan suatu undang-undang dalam suatu negara modem yang telah memunculkan berbagai kompleksitas permasalahan yang dihadapinya, sebagai perbandingan dapat dikemukakan contohnya adalah The Federal Parliament Australia yang telah meloloskan 1182 Acts dalam tahun 1960 an dan 1684 Acts dalam 
Sebagai negara yang telah memilih prinsip demokrasi dan dipadukan dengan prinsip negara hukum, Indonesia akan menata tertib hidup dan kehidupan dalam bermasyarakat, berbangsa dan bernegara menggunakan aturan hukum yang demokratis. Dengan kata lain, bangsa Indonesia akan membangun tatanan kehidupan bersama dalam wadah negara Indonesia yang demokratis dan didasarkan pada aturan hukum. Artinya bangsa Indonesia akan meletakkan prinsip demokrasi dan prinsip hukum sebagai suatu sinergi yang saling bersimbiose-mutualistik dalam mewujudkan adanya national legal order $r^{10}$ yang demokratis dalam negara Oleh karena itu, keberadaan undang-undang yang merupakan sub sistem dari sistem hukum nasionalmenempati peran yang penting dalam rangka pembangunan sistem hukum nasional dalam suatu negara.

Dalam rangka membentuk negara sebagai tertib hukum nasional ini, perlu dilakukan perbaikan tata cara pembentukan undangundang yang partisipatif. Pada masa Orde Lama dan Orde Baru proses pembentukan undang-undang sebagian besar dilakukan secara sepihak oleh penguasa tanpa melibatkan masyarakat luas. Atas dasar kenyataan tersebut, maka proses pembentukan undang-undang $\mathrm{di}$ era reformasi ini perlu dilakukan secara partisipatif dengan melibatkan masyarakat agar dihasilkan undang-undang yang diterima oleh masyarakat luas, tidak hanya diterima oleh legislator saja." Partisipasi masyarakat dalam proses pembangunan -termasuk di bidang pembentukan undang-undang ini- telah menjadi issue penting dalam konteks global dewasa ini. ${ }^{12}$

Bertalian dengan pembentukan undangundang yang partisipatif ini, di. dalamnya mengandung dua makna yaitu proses dan substansi. Pertama, bahwa proses atau mekanisme dalam pembentukan undangundang harus dilakukan secara transparan sehingga masyarakat dapat berpartisipasi memberikan masukan-masukan dalam mengatur suatu persoalan. Kedua, bahwa substansi materi yang akan diatur harus ditujukan bagi kepentingan masyarakat luas sehingga menghasilkan suatu undang-undang yang demokratis. Dengan demikian antara transparansi, partisipasi dan demokratisasi dalam pembentukan undang-undang merupakan satu kesatuan yang utuh dan tidak dapat dipisahkan dalam suatu negara demokrasi. Apabila pembentukan undangundang telah melalui proses partisipatif, tranparan dan demokratis, maka pada gilirannya diharapkan undang-undang yang dihasilkannya akan diterima oleh masyarakat luas dengan penuh kesadaran.

\footnotetext{
tahun 1970-an. Dan pembentukan undang-undang ini masih akan terus berlangsung dalam tahun-tahun mendatang. Lihat Roman Tomasic, Legislation and Society in Australia (Australia: The Law Foundation of New South Wales, 1979), pada bagian Preface dan hlm. 9.

${ }^{10} \mathrm{Hans}$ Kelsen, General Theory of Law and State (New York: Russel \& Russel A Division of Atheneum Publisher, Inc., 1961), hIm. 181.

"Terence Ingman, The English Legal Process (London: Blackstone Press Limited, 1983), hlm. 181.

${ }^{12}$ Gary Craig and Marjorie Mayo (Editor), Community Empowerment AReader in Participation and Development (London \& New Jersy: Zed Books Ltd., 1995), hlm. 1.
} 
Tuntutan partisipatif perlu dilakukan agar warga masyarakat yang akan terkena sebagai objek dari suatu undang-undang dapat memberikan sumbangan pikirannya berupa materi-materi muatan yang akan diaturnya. Keterlibatan masyarakat ini penting mengingat pada akhirnya masyarakat juga yang akan menerima dampak dengan dikeluarkannya suatu undang-undang. Dengan demikian proses pembentukan undang-undang akan terjadi suatu proses yang buttom up. Artinya, masyarakat yang terkait langsung dengan kehadiran suatu undang-undang, akan merasa ikut melahirkan undang-undang melalui berbagai keterlibatan dalam bentuk masukanmasukan yang diberikannya. Meskipun partisipasi ini bukan jaminan bahwa suatu undang-undang yang dihasilkannya akan dapat berlaku effektif di masyarakat, tetapi langkah yang ditempuh oleh lembaga legislatif dalam setiap pembentukan undang-undang, setidak-tidaknya dapat diharapkan undangundang akan lebih diterima dan berlaku effektif di masyarakat.

Sejarah legislatif di tanah air pernah mencatat kenyataan pahit berupa ditolaknya
RUU Penanggulangan Keadaañ Bahaya (RUU PKB) yang telah diproses melalui prosedur dan tata cara sesuai dengan ketentuan peraturan perundang-undangan. RUU PKB ini berkaitan dengan pengaturan masalah negara dalam keadaan bahaya, suatu undang-undang yang akan diberlakukan manakala negara dalam keadaan darurat khusus, militer maupun darurat perang. Akan tetapi, undang-undang ini gagal disahkan dan tidak diundangkan oleh Presiden karena terdapat sekelompok masyarakat terutama mahasiwa dan kelompok profesional yang menolak dengan keras kehadiran RUUPKB tersebut. Penolakan RUU PKB oleh sekelompok mahasiswa dan kelompok profesional ini menjadi-pelajaran yang sangat berharga bagi proses pembentukan undang-undang, agar proses partisipatif dari masyarakat yang akan dikenai suatu undang-undang diperhatikan oleh pembentuk undang-undang. ${ }^{13}$

Sementara itu tuntutan transparansi dalam proses pembentukan undang-undang perlu dilakukan agar undang-undang yang dihasilkannya dapat diketahui oleh masyarakat luas sejak awal proses persiapan dan

\footnotetext{
${ }^{13}$ Gelombang perlawanan terhadap dibahasnya RUU politik, Kamis (9/9), berunjuk rasa menuju Gedung DPR menyatakan penolakan terhadap RUU Penanggulangan Keadaan Bahaya. Pada dasamya penolakan ini karena kekhawatiran akan terjadinya militerisme dalam penyelenggaraan pemerintahan. Lihatharian Kompas, Makin Gencar, Aksi Menantang RUU Keselamatan Negara, harian Kompas, Jum'at, 10-09-1999, hlm. 1. Lhat pula harian Kompas, Bentrok Unjuk Rasa Mahasiswa Menentang Keselamatan dan Keamanan Negara yang telah diubah namanya menjadi RUU Penanggulangan Keadaan Bahaya, semakin gencar. Sekitar 1000 mahasiswa, kalangan profesional, dan aktivis partai menentang RUU Keadaan Bahaya, harian Kompas, Sabtu, 11-09 - 1999, him. 1. Lihatpula harian Kompas, Dalam RUU Penanggulangan Keadaan Bahaya Kebebasan Pers Harus Tetap Terjamin, harian Kompas, Selasa, 14-09-1999, hlm. 15. Belajar dari pengalaman penolakan RUU PKB yang telah disetujui DPR tetapi tidak disahkan dan diundangkan oleh Presiden inilah, maka dalam Amandemen Kedua UUD 1945 tahun 2000 telah ditegaskan adanya ketentuan yang menyatakan bahwa "Dalam hal rancangan undang-undang yang telah disetujuibersama tersebut tidak disahkan oleh Presiden dalam waktu tiga puluh hari semenjak rancangan undang-undang tersebut disetujui, rancangan undang-undang tersebut sah menjadj undang-undang dan wajib diundangkan". Lihat Pasal 20 ayat (5) UUD 1945.
} 
pembahasannya. Proses pembentukan undang-undang yang tidak dilakukan secara transparan, akan berdampak kurang baik bagi masyarakat.

Dalam sejarah ketatanegaraan, Presiden bersama-sama DPR pernah mengeluarkan Undang-undang No. 14 Tahun 1992 tentang Lalu-lintas dan Angkutan Jalan Raya. Kehadiran undang-undang ini membuat masyarakat terkejut oleh adanya sanksi'yang dirasa terlalu berat bagi pelanggar ketentuan undangundang ini. Keterkejutan masyarakat ini disebabkan karena proses pembentukan Undangundang tentang Lalu Lintas dan Angkutan Jalan Raya ini tidak dilakukan secara transparan kepada masyarakat luas. Dalam kasus pembentukan undang-undang ini keputusan diambil secara sepihak oleh lembaga legislatif tanpa melibatkan masyarakat luas. Dengan demikian dalam proses pembentukan Undang-undang No. 14 Tahun 1992 tidak ada masukan-masukan baik dari masyarakat maupun lembaga-lembaga di luar pemerintah lainnya. ${ }^{14}$

Selanjutnya masalah demokratisasi dalam proses pembentukan undang-undang bertalian dengan logika pemikiran yang sederhana bahwa undang-undang dalam suatu negara yang demokratis tentu tidak akan keluar dari kepentingan orang banyak. Artinya bahwa adanya suatu undang-undang harus dapat memberikan ketenangan dan jaminan bagi kepentingan hidup masyarakat luas. Sebab, rakyat melalui sarana pemilihan umum telah memberikan kepercayaannya kepada wakilnya yang duduk di DPR. DPR inilah bersama-sama dengan Presiden - suatu lembaga yang konstitusional memegang kekuasaan legislatif- mengatur masyarakat melalui berbagai undang-undang yang telah dikeluarkannya. Oleh karena itu, secara teoritik undang-undang yang dihasilkan oleh lembaga legislatif, seharusnya diterima oleh másyarakat luas karena kepentingannya tertampung dalam proses pembentukan undang-undang.

Dalam sejarah perjalanan bangsa yang diperankan oleh Orde Baru selama 32 tahun dan akhirnya tumbang oleh gerakan reformasi 1998, tampak bahwa berbagai undangundang hanya dipakai sebagai justifikasi bagi kepentingan-kepentingan politik oleh sekelompok orang yang berkuasa. Hal ini berarti bahwa undang-undang tidak responsif terhadap nasib masyarakat luas, tetapi lebih bersifat konservatif dan ortodoks dalam rangka mempertahankan status quo pemerintah. ${ }^{15}$

${ }^{14}$ Sebenamya proses penyusunan UU Lalu Lintas dan Angkutan Jalan Raya (UU LLAJR) tidak digarap secara terburu-bun, karena RUUnya telah diajukan oleh pemerintah tanggal 24 Mei 1991, kemudian dibahas di DPR dan akhimya sampai disahkan oleh Presiden bulan Mei 1992. Jadi secara teoritis, mustinya norma hukum yang dituangkan dalam UU itu sudah dipikirkan secara matang olehpemerintah dan DPR. Akan tetapi toh reaksi keras tetap bermunculan. Reaksi itu muncul bukan pada saat disahkan Presiden, tetapi ketika seorang Kepala Kantor Wilayah Perhubungan of Jawa Barat, AS Sunandhi, mengingatkan bahwa UU LAJR akan mulai berlaku 17 September 1992, sehingga masyarakat diharapkan mulai bersiap diri. Hebatnya yang kaget bukan cuma masyarakat, tapi juga beberapa anggota DPR sendiri maupun pejabat pemerintah, yang seolah merasa "kecolongan". Lihat Kompas, Tajuk Rencana, Undang-undang Lalu Lintas dan Reaksi-reaksi Yang Muncul, Kompas, Selasa, 21-07-1992, hlm. 4.

${ }^{15}$ Moh. Mahfud MD, Politik Hukum di Indonesia, Cetakan Pertama, (Jakarta: LP3ES, 1998), hIm. 15. 
Dampak dari adanya undang-undang yang konservatif dan ortodoks ini diberikan reaksi keras oleh masyarakat luas karena kepentingannya terabaikan.

Sebagaimana diketahui, gerakan reformasi yang lalu pada mulanya menuntut dicabutnya seperangkat perundang-undangan di bidang politik produk Orde Baru yaitu: Undang-undang Pemilihan Umum, Undang-undang Susunan dan Kedudukan MPR, DPR dan DPRD, Undang-undang Partai Politik dan Golongan Karya, Undang-undang Referendum dan Undang-undang Pemerintahan di Daerah. ${ }^{16}$ Kehadiran berbagai undang-undang tersebut ditolak oleh masyarakat karena lebih merupakan kepanjangan tangan pemerintah dalam upaya mempertahankan kekuasaan dengan berlindung dibalik faham konstitusionalisme. Kondisi ini menjadi sangat aneh dan ganjil, mengingat dalam suatu negara demokrasi, mekanisme hukum seharusnya berjalan dari rakyat, oleh rakyat, untuk rakyat dan ditegakkan oleh rakyat. Dengan demikian tentunya tidak akan terjadi gejolak masyarakat yang menolak kehadiran berbagai undang-undang hasil karya dari lembaga legislatif.

Akibat yang ditimbulkan' dengan adanya berbagai undang-undang yang konservatif dan tidak demokratis ini ternyata sangat mendasar bagi tatanan kehidupan bermasyarakat, berbangsa dan bernegara. Hampir tidak dapat dipercaya kalau pemerintahan Orde Baru yang telah berkuasa selama 32 tahun dengan cengkeraman otoritarian serta berbagai perangkat perundang-undangan yang telah disiapkannya, akhirnya tumbang oleh gerakan moral yang bersumberkan pada keadilan dan nurani masyarakat. Semua mengetahui bahwa dalam menuju proses demokratisasi yang diawali dengan gerakan reformasi harus dibayar mahal dalam berbagai tatanan kehidupan di segala bidang. Inilah akibat yang harus ditanggung bersama oleh segenap lapisan masyarakat yang disebabkan oleh ulah sekelompok orang dengan menggunakan sarana undang-undang sebagai alat untuk meraih kekuasaan. Dengan kata lain proses pembentukan undang-undang di masa Orde Baru telah gagal dalam mempertanggungjawabkan kepada publik guna menuju proses perubahan sosial yang tertib, damai dan berkesinambungan. Akan tetapi justeru yang terjadi adalah krisis multi dimensi yang sampai awal 2003 belum juga tampak akan tandatanda penyelesaiannya. Oleh karena itu, pertanggungjawaban dalam pembentukan

${ }^{18}$ Aksi demonstrasi ribuan mahasiswa Universitas Indonesia kembali berlangsung di area Kampus UI Depok, Kamis (26/2). Seperti juga aksi keprihatinan yang dilakukan Ikatan Alumni Universitas Indonesia (lluni) sehari sebelumnya di Salemba Ul, aksi unjuk rasa mahasiswa kali ini menuntut dilaksanakannya reformasi di bidang politik dan ekonomi dalam mengatasi krisis yang melanda Indonesia. Lihatharian Kompas, Mahasiswa Gelar Aksi Keprihatinan, harian Kompas, Jum'at, 27 - 02 - 1998, hlm. 3. Lihat pula harian Kompas, Aksi Keprihatinan Mahasiswa Berlanjut di Berbagai Kampus, harian Kompas, Rabu, 11 - 03-1998, hlm. 3. Lihat pula harian Kompas, Mahasiswa UI Serahkan Dokumen Reformasi Politik, Belasan Ribu'Mahasiswa UGM Adakan Aksi Keprihatinan, harian Kompas, Jum'at, 06 -03- 1998, hlm. 3. Lihat pula harian Kompas, Aksi Keprihatinan Mahasiswa Diwamai Bentrokan, harian Kompas, Kamis, 12-03-1998, h/m. 3. Lihat pula harian Kompas, Presiden Soeharto: Mengubah UU Politik Tak Semudah Mengucapkannya, harian Kompas, Selasa, 14-04-1998, hlm. 3. 
undang-undang ini penting mengingat Indonesia adalah sebagai suatu negara demokrasi yang berdasarkan atas hukum: Dengan demikian prinsip demokrasi yang secara sederhana dikatakan pemerintahan dari rakyat oleh rakyat dan untuk rakyat tercermin juga dalam proses pembentukan undang-undang.

Berbagai kenyataan yang telah diungkapkan di atas, tampaknya tidak terlepas dari konfigurasi politik di masa Orde Baru yang bukan demokratis-karena lebih menonjolkan langgam otoritarian, sehingga. keputusankeputusan bidang legislasi lebih banyak diwarnai oleh visi politik pemerintah. ${ }^{17}$ Perwujudan dalam mengatur perancangan perundang-undangan dalam konfigurasi yang otoritarian ini adalah dikeluarkannya Instruksi Presiden No. 15 tahun 1970 yang tidak memberikan tempat bagi adanya partisipasi masyarakat. Selanjutnya memasuki era reformasi, Instruksi Presiden ini telah diganti dengan Keputusan Presiden No. 188 Tahun 1998, tetapi di dalamnya juga tidak secara tegas harus melibatkan partisipasi masyarakat dalam proses perancangan perundangundangan. ${ }^{18}$ Demikian pula dalam Surat Keputusan DPR No. 03ADPR RI///2000-2001 tentang Peraturan Tata Tertib DPR RI belum memberikan tempat bagi masyarakat luas dalam proses pembentukan undang-undang. ${ }^{19}$ Menyadari akan adanya berbagai kelemahan tersebut, maka Badan Legislasi DPR bertekad akan memperbaiki mekanisme pembahasan RUU baik melalui RUU Tata Cara Pembentukan Peraturan Perundang-undangan maupun Peraturan Tata Tertib DPR. ${ }^{20}$

Dengan melihat pada proses pembentukan undang-undang yang telah diperankan oleh Orde Baru tersebut, maka pada masa transisi yang diperankan oleh Era Reformasi sekarang ini, harus dapat mengambil hikmah dan pelajaran yang baik dari kegagalan masa lalu dalam proses pembentukan undang-undang. Pemerintahan transisi harus mampu memberikan warna yang berbeda dalam proses pembentukan undang-undang. Terlebih lagi sekarang ini euforia politik sedang terjadi di segala aspek kehidupan, maka dalam hal pembentukan undang-undang pun harus dilakukan terobosan dengan mengacu kepada adanya transparansi, partisipatif dan demokratisasi.

Atas dasar kenyataan tersebut, maka persoalan yang akan muncul adalah bagaimana mewujudkan proses pembentukan undangundang yang transparan, partisipatif dan demokratis? Sebab, permasalahan ini pasti akan berbenturan dengan kewenangan

${ }^{17}$ Moh. Mahfud MD, op. cit., hlm. 375.

${ }^{18}$ Lihat Instruksi Presiden No. 15 Tahun 1970 dan Keputusan Presiden No. 188 Tahun 1998 yang samasama mengatur tentang tata cara mempersiapkan rancangan peraturan perundang-undangan.

. ${ }^{1}$ Lihat Bab tentang Pembentukan Undang-undang Surat Keputusan DPR No. 03ADPRR RI//2000-2001. Selanjutnya dalam Pasal 22 AUUD 1945 masalah tata cara pembentukan undang-undang ini akan ciatur. lebih lanjut dengan undang-undang, akan tetapi hingga awal 2003 ini baru sampai tahap penyelesaian tentang RUU nya baik yang diajukan oleh Pemerintah maupun dari DPR.

${ }^{20}$ Harian Kompas, 22- 1- 2003 
konstitusional yang diberikan kepada Presiden dan DPR sebagai lembaga legislatif dalam UUD 1945. Dalam Pasal 5 ayat (1) dan Pasal 20 ayat (1), (2), (3), (4) dan (5) UUD 1945yang telah diamandemen mengatur secara tegas tentang kewenangan pembentukan undangundang sebagai berikut:

Pasal 5 ayat (1) menentukan:

"Presiden berhak mengajukan rancangan undang-undang kepada Dewan Perwakilan Rakyat."

Pasal 20 ayat (1), (2), (3), (4) dan (5) menentukan:

Ayat (1):

"Dewan Perwakilan Rakyat memegang Ayat (2):

kekuasaan membentuk undang-undang

"Setiap rancangan undang-undang dibahas oleh Dewan Perwakilan Rakyat dan Presiden . untuk mendapat persetujuan bersama"

Ayat (3):

"Jika rancangan undang-undang tidak mendapat persetujuan bersama, rancangan undang-undang itu tidak boleh diajukan lagi dalam persidangan Dewan Perwakilan Rakyat masa itu" Ayat (4):

"Presiden mengesahkan rancangan undang-undang yang telah disetujui bersama untuk menjadi undang-undang" dan

Ayat (5):

"Dalam hal rancangan undang-undang yang telah disetujui bersama tersebut tidak disahkan oleh Presiden dalam waktu tiga puluh hari semenjak rancangan undang- undang undang-undang tersebut disetujui, rancangan undang-undang tersebut sah dan menjadi undangundang". ${ }^{21}$

Atas dasar pasal-pasal tersebut jelas bahwa kekuasaan legislatif (pembentuk undang-undang) menurut UUD 1945 dilakukan oleh dua organ sekaligus secara bersamasama yaitu Presiden dan DPR, meskipun tekanannya diletakkan pada DPR. Presiden bertindak sebagai organ yang akan melaksanakan undang-undang, sedangkan DPR yang keanggotaannya disi melalui pemilihan umum bertindak dalam kapasitas sebagai wakil rakyat yang akan menyuarakan aspirasi rakyat. Apakah keterwakilan rakyat melalui DPR yang diisi melalui pemilihan umum tersebut tidak cukup representatif dalam proses pembentukan undang-undang? Apabila rakyat tetap akan dilibatkan dalam proses pembentukan undang-undang, maka permasalahan yang muncul adalah sejauh mana transparansi, partisipatif dan demokratisasi dapat diterima dalam proses pembentukan undang-undang?

Sejumlah pertanyaan di atas, tampaknya tidak mudah untuk dicarikan penyelesaiannya. Sebab, ketika pembentuk undang-undang tidak tranparan, partisipatif dan demokratis sebagaimana diperankan oleh Orde Barupada akhirnya masyarakat menggugatnya melalui gerakan reformasi. Akan tetapi ketika proses pembentukan undang-undang pintu transparansi, partisipatif dan demokratisasi dibuka selebar-lebarnya, maka tentu akan menggeser kewenangan konstitusional yang telah diberikan oleh UUD 1945. Artinya,

${ }^{21}$ UUD 1945 dan Amandemennya (Pabelan, Surakarta, 2000), hlm. 65-73. 
Presiden dan DPR sebagai pemegang kekuasaan legislatif akan tertandingi dalam proses pembentukan undang-undang. Sudah barang tentu transparansi, partisipatif dan demokratisasi yang terlalu luas inipun tidak akan memberikan hasil yang positif bagi pembangunan kelembagaan yang secara formal diatur dalam UUD 1945.

Oleh karena itu, perlu dicarikan jalan pemecahan yang sebaik-baiknya, yang dapat menjamin dan melindungi antara kepentingan kelembagaan dan kepentingan transparansi, partisipatif dan demokratisasi dalam proses pembentukan undang-undang. Sebab, tanpa adanya penataan yang seimbang antara kepentingan kelembagaan dan tranparansi, partisipatif dan demokratisasi, undang-undang yang dihasilkan akan tetap pincang. Hasil yang dicapainya tidak akan dapat secara optimal menampung berbagai kepentingan yang secara riil ada dalam tatanan kehidupan bermasyarakat, berbangsa dan bernegara.

Dengan mengacu pada pemaparan masalah di muka, terdapat tiga rumusan permasalahan pokok yang dapat diajukan dalam tulisan ini: pertama, bagaimana partisipasi masyarakat dalam proses pembentukan undang-undang di indonesia pada masa Orde Baru dan Era Reformasi? Kedua, bagaimana proses pembentukan undang-undang yang melibatkan partisipasi masyarakat di Indonesia sehingga melahirkan undang-undang yang partisipatif? Ketiga, apakah syarat-syarat yang diperlukan sehingga partisipasi masyarakat dalam proses pembentukan undang-undang dapat dipertimbangkan dan diterima oleh lembaga legislatif?

Dengan melihat pada berbagai permasalahan tersebut, maka permasalahan dalam tulisan ini terletak dalam disiplin ilmu hukum khususnya ilmu pengetahuan perundangundangan, ${ }^{22}$ yaitu ilmu pengetahuan interdisipliner tentang pembentukan peraturan perundang-undangan. IImu pengetahuan perundang-undangan ini dibagi dalam teơri perundang-undangan dan ilmu perundangundangan. Teori perundang-undangan bersifat kognitif berorientasi kepada menjelaskan dan menjernihkan pemahaman. Sedangkan ilmu perundang-undangan bersifat normatif berorientasi kepada melakukan perbuatan pengaturan yang masih dibagi lagi dalam proses perundang-undangan, metoda perundang-undangan dan teknik perundangundangan. ${ }^{23}$ Keberadaan ilmu perundangundangan sebagai suatu cabang disiplin ilmu hukum memang masih muda ${ }^{24}$ apabila dibandingkan dengan cabang ilmu hukum lainnya seperti ilmu hukum tata negara, ilmu hukum administrasi negara dan lain-lain. Oleh karena itu, tidak mengherankan jika keberadaan ilmu perundang-undangan ini masih menjadi wacana perdebatan sebagai suatu disiplin ilmu yang telah memenuhi objek, metode

${ }^{22}$ A. Hamid S Attamimi,"Teori Perundang-undangan Indonesia: Suatu Sisi llmu Pengetahuan Perundangundangan Indonesia yang Menjelaskan dan Menjernihkan Pemahaman, ${ }^{\circ}$ Pidato Pengukuhan Jabatan Guru Besar Tetap Pada Fakultas Hukum Universitas Indonesia, Jakarta, 1992, hlm. 21.

${ }^{23}$ ibid.

${ }^{24}$ Abdurrahman, IImu Hukum, Teori Hukum dan Ilmu Perundang-undangan, Cetakan I, (Bandung: Citra Äditya Bakti, 1995), hlm. 173. 
penyelidikan, sistimatisasi dan universalitasnya. Atas dasar telaah pemahaman unsur-unsur keilmuan tersebut, maka terdapat pula pendapat yang melihat persoalan perundangundangan lebih tepat ditempatkan sebagai teori perundang-undangan.$^{25}$ Terlepas dari adanya perbedaan pendapat tersebut masalah perundang-undangan akan semakin diperlukan di masa-masa yang akan datang seiring dengan perkembangan masyarakat. Oleh karena itu, kajian terhadap persoalan perundang-undangan ini perlu terus dilakukan untuk membangun landasan yang kuat dalam mengembangkan pengetahuan yang bertalian dengan perundang-undangan.

\section{Idealita Pembentukan Peraturan Perundang-undangan}

Cita-cita pembentukan hukum nasional yang akan berfungsi untuk menyebarkan dan memelihara suatu alokasi nilai-nilai yang oleh masyarakat dirasa benar, ${ }^{26}$ telah lahir tumbuh dan berkembang semenjak berdirinya Negara Republik Indonesia 17 Agustus 1945. Dengan kemerdekaan, bangsa Indonesia akan melakukan perubahan sosial melalui tatanan hukum nasional yang sejalan dengan jiwa, semangat dan alam kemerdekaan. ${ }^{27}$ Pembentukan tatanan hukum nasional ini akan diwujudkan dalam berbagai peraturan perundang-undangan dan harus tetap berada dalam bingkai landasan konstitusional UUD 1945. ${ }^{28}$

Bertalian dengan peraturan perundangundangan ini, dalam UUD 1945 telah dimuat sendi-sendi dasarnya yaitu sendi kerakyatan (demokrasi), ${ }^{29}$ negara berdasar atas hukum ${ }^{30}$

\footnotetext{
${ }^{25}$ Rosjidi Ranggawidjaja, Pengantar Ilmu Perundang-undangan Indonesia, Cetakan I, (Bandung: Mandar Maju, 1998), hlm. 13-20.

${ }^{26}$ Lawrence M. Friedman, op.cit., hlm. 17.

${ }^{27}$ Sebagai konsekuensi logis dari Proklamasi, pada saat itu mulai berdri tata hukumbaru, yaitu Tata Hukum Indoinesia dengan Proklamasi tersebut sebagai "tindakan pertama" atau "ketentuan pertama" atau "noma pertama" atau dapatjuga disebut sebagaj "ketentuan pangkal"nya. Lihat Joeniarto, Selayang Pandang Tentang Sumber-sumber Hukum Tata Negara di Indonesia, Ctk. IV, (Yogyakarta: Liberty, 1983), hIm. 19.

${ }^{28}$ Dengan adanya gerakan mahasiswa 1998 yang melahirkan era reformasi, telah merubah tatanan secara mendasar dalam kehidupan ketatanegaraan Indoneasia. Hal ini dapat dilihat pada Perubahan UUD 1945yang sampai dengan tahun2002 telah mengalami empatkali Perubahan yakni Perubahan Pertama 1999, Perubahan Kedua2000, Perubahan Ketiga 2001 dan Perubahan Keempat 2002.

${ }^{29}$ Gagasan demokrasi yang diperjuangkan sejak masa perjuangan sebelum Indonesia merdeka adalah yang sesuai dengan Indonesia sendiri, yang tentu saja berbeda dengan Barat yangberlatar filsafat individualisme, liberalisme dan kapitalisme. Tetapi dengan mengkritik individualisme, tidak serta merta menjadikan mereka terposisikan dalam Marxisme yang merupakan anti tesis atas individualisme-liberalisme dankapitalisme. Tokohtokoh bangsa ketika itu menghendaki sifat kerakyatan yang asli, dan yang dijdjalkan adalah justru paham kolektivisme. Lihat Jimly Asshiddigie, Gagasan Kedaulatan Rakyat Dalam Konstitusi dan Pelaksanaannya di Indonesia, Cetakan Pertama, (Jakarta: IkhtiarBaru Van Hoeve, 1994), hlm. 30-31.

${ }^{30} \mathrm{Negara}$ hukum atau yang lebih tepat adalah negara yang berdasar atas hukum ini merupakan genus begrip, sedangkan sebagai species begrip konsep negara hukum ini mempunyai lima macam yaitu: nomokrasi Islam, the rule of law, rechtsstaat, socialist legality dan negara hukum Pancasila. Lihat M Tahir Azhary, Negara Hukum: Suatu Studi tentang Prinsip-prinsipnya Dilihat dari Segi Hukum Islam, Implementasinya pada Periode
} 
dengan konstitusi sebagai hukum dasar tertinggi (konstitusionalisme). ${ }^{31}$ Dengan demikian peraturan perundang-undangan yang akan digunakan untuk mengatur kehidupan bersama dalam wadah Negara Kesatuan Repubilik Indonesia harus dituangkan dalam sistem konstitusionalisme yang berada di dalam konsepsi negara hukum yang demokratis atau negara demokrasi yang berdasarkan atas hukum. ${ }^{32}$ Di sini tampak jelas sekali adanya keterkaitan konsepsi demokrasi, negara hukum dan konstitusionalisme yang harus menjadi pedoman dalam membuat undang-undang. Oleh karena itu, uraian selanjutnya akan menyajikan pemikiran-pemikiran yang bertalian dengan konsep demokrasi, demokrasi elitis, demokrasi partisipatoris, partisipasi, negara hukum, konstitusi dan undang-undang.

\section{Konsep Demokrasi}

Sebagaimana telah diketahui kata demokrasi (democracy) berasal dari dua akar kata bahasa Yunani Kuno yaitu "demos" rakyat dan "kratein", pemerintahan; jadi demokrasi berarti pemerintahan oleh rakyat. Di Athena, kata demokrasi digunakan untuk menunjuk pada "government by the many" (pemerintahan oleh orang banyak), sebagai lawan dari "government by the few" (pemerintahan oleh sekelompok orang). Dengankatalain "demokras" dalam pengertian yang agak lengkap dapat diberikan rumusan sebagai berikut:

"a system of government in which those who have authority to make decisions (that have the force of law) acquire and retain this authority either directly or indirectly as the result of winning free elections in which the great majority of adult citizens are allowed to participate." 33

Dari rumusan di atas, kiranya dapat diberikan pemahaman terhadap suatu negara yang menganut sistem demokrasi yaitu: pertama, demokrasi adalah suatu sistem pemerintahan yang mempunyai unsur-unsur atau elemen-elemen yang saling terkait dan tidak dapat dipisahkan. Kedua, orang-orang yang memegang kekuasaan atas nama demokrasi dapat mengambil keputusan untuk menetapkan dan menegakkan hukum. Ketiga,

Negara Madinah dan Masa Kini, Ctk. Pertama, (Jakarta: Bulan Bintang, 1992), hlm. 63.

${ }^{31}$ Bagir Manan, "Dasar-dasar Konstitusional Peraturan Perundang-undangan Nasional, "disajikan dalam pendidikan singkat Kajian Perundang-undangan untuk para pengajar Fakultas Hukum se Sumatera, yang diselenggarakan oleh Fakultas Hukum Universitas Andalas, tanggal 11 - 18 Oktober 1993, him. 9- 11.

${ }^{32}$ Dinamika pemikiran mengenai konsep pemikiran negara yangberdasar atas hukum dari negara kerakyatan (demokrasi) ini sudah berlangsung sejak dari jaman Yunani dan Romawi Kuno. Lihat Jimly Asshiddiqie, op. cit, hlm. 11. Lihat juga Moh. Kusnardi dan Bintan R Saragih, Ilmu Negara, Ctk. Ketiga, (Jakarta: Gaya Medja Pratama, 1995), hlm. 164. Bandingkan dengan Miriam Budiardjo yang melihat demokrasi dari "demos" berarti rakyat dan kratos/kratein ýang berarti kekuasaan /berkuasa, sehingga demokrasi berarti: "rakyat berkuasa" atau "govemment or rule by the people." Atas dasar perumusan tersebut Miriam Budiardjo melihat adanya berbagai macam demokrasi yaitu: Demokrasi Konstitusional, Demokrasi Parlementer, Demokrasi Terpimpin, Demokrasi Pancasila, Demokrasi Rakyat, Demokrasi Soviet, Demokrasi Nasional dsb. Lihat Miriam Budjardjo, Dasar-dasar IImu Politik, Ctk. VIll , (Jakarta: Gramedia, 1983), him. 50.

${ }^{33}$ James MacGregor Bums at all, Government By The People, Thirteenth Altemate Edition, (New Jersey: Prentice Hall, Englewood Cliffs, 1989), him. 3. 
kekuasaan untuk mengatur dalam bentuk aturan hukum tersebut diperoleh dan dipertahankan melalui pemilihan umum yang bebas dan dilikuti oleh sebagian besar warga negara dewasa dari suatu negara. Berdasarkan pada tiga ciri-ciri.umum tersebut, maka suatu negara demokrasi mempunyai tiga pemahaman utama yang meliputi hakekat, proses.dan tujuan daridemokrasi, ${ }^{34}$ Dengankata lain demokrasi adalah sistem pemerintahan yang dibentuk melalui pemilihan umum untuk mengatur kehidupan bersama atas dasar aturan hukum yang berpihak pada rakyat banyak. Jadi, sangat tepat kiranya demokrasi diberikan rumusan yang singkat, padat dan populair sebagai "a government of the people, by the people, for the people ${ }^{\mathrm{a}} .{ }^{35}$

Atas dasar pemahaman tentang demokrasi sebagaimana dikemukakan secara singkat di atas, maka pilihan terhadap negara demokrasi sudah barang tentu mempunyai konsekuensikonsekuensi yang harus diperhatikan. Konsekuensi-konsekuensi ini akan memberikan kesempatan kepada rakyat selaku warga negara untuk melakukan hak dan kewajiban politiknya dalam bernegara. Sebab, dengan demokrasi akan memberikan kesempatankesempatan untuk, pertama, partisipasi yang efektif; kedua, persamaan dalam memberikan suara; ketiga, mendapatkan pemahaman yang jernih; keempat, melaksanakan pengawasan akhir terhadap agenda; kelima, pencakupan orang dewasa. ${ }^{36}$ Adanya konsekuensi-konsekuensi ini akan memberikan ukuran-ukuran dalam melihat berbagai negara yang mengklaim sebagai negara demokrasi. Dengan katalain, ketikakesempatankesempatan yang merupakan konsekuensi dari ukuran umum negara demokrasi ini tidak dijalankan, maka negara tersebut tidak dapat dikualifikasikan sebagai negara demokrasi.

Dari awal kelahirannya pada masa Yunani Kuno usia demokrasi telah berjalan sekitar 2500 tahun, dan dalam perkembangannya telah mengalami dua kali bentuk transformasi demokrasi yaitu:-pertama, transformasi demokrasi negara kota di Yunani dan Roma Kuno pada abad ke V SM serta beberapa negara kota di Italia pada masa Abad Pertengahan. Kedua, transformasi yang terjadi dari demokrasi negara kota menjadi ke dalam demokrasi kawasan bangsa, negara, atau negara nasional yang luas. ${ }^{37}$

Adanya dua bentuk transformasi tersebut, telah mengubah tatanan secara mendasar bentuk demokrasi sebagai akibat terjadinya perpindahan dari negara kota ke negara bangsa. Robert A Dahl mengemukakan

${ }^{34}$ Bandingkan dengan Samuel PHuntington yang melihat demokrasi dalam tiga pendekatan umum yaitu: pertama, sumber wewenang bagi pemerintah; kedua, tujuan yang dilayani oleh pemerintah; dan ketiga, proseduruntuk membentuk pemerintahan. Lihat Samuel P Huntington dalam: Gelombang Demokratisasi Ketiga, Penejemah Asril Marjohan, Ctk. Kedua, (Jakarta: Pustaka Utama Grafitri, 1995). hlm. 4.

${ }^{35}$ Harris G. Warren at all, Our Democracy at Work, (USA: Printice Hall, Inc., Englewood Cliffs, 1963), hilm. 2.

${ }^{36} \mathrm{Dalam}$ hal ini RobertA Dahl mengemukakan bahwa "Democracy provides opportunities for. 1. effective participation; 2. equality in voting; 3. gaining enlightened understanding; 4. exercising final control over the agenda; 5 . inclusion of adults". Lihat Robert A Dahl, Democracy, (USA: Yale University Press, 1998), hlm. 38.

${ }^{37}$ Robert A Dahl, Demokrasi dan Para Pengkritiknya, Jilid Il, Ditejemahkan oleh A Rahman Zainuddin, Edisi Pertama, (Jakarta: Yayasan Obor Indonesia, 1992), hlm. 3-4. 
adanya delapan akibat yang ditimbulkan adanya penerapan demokrasi pada wilayah negara bangsa yang luas. Akibat-akibat ini adalah perwakilan, perluasan yang tidak terbatas, batas-batas demokrasi partisipatif, keanekaragaman, konflik, poliarki, pluralisme sosial \& organisasional dan .perluasan hakhak pribadi. ${ }^{38}$ Oleh karena itu bentuk dan susunan negara demokrasi pada masa Yunani Kuno sangat berbeda dengan bentuk dan susunan negara demokrasi pada jaman sekarang.

Pada negara kota bentuk demokrasinya dilakukan secara langsung, yaitu rakyat berkumpul di suatu tempat yang dinamakan ecclesia ${ }^{39}$ untuk memecahkan secara langsung masalah yang muncul secara bersama-sama. Oleh karena itu demokrasi di negara kota pada masaYunani Kuno dikenal pula sebagai demokrasi partisipatif ${ }^{40}$ dan tidak mengenal lembaga perwakilan. Sedangkan untuk negara bangsa dengan wilayah negara yang luas adalah sulit atau bahkan tidak mungkin untuk mempraktekkan model demokrasi langsung. ${ }^{41}$ Pada negara-negara modern dikembangkan model demokrasi tidak langsung melalui lembaga perwakilan. ${ }^{42}$ Oleh karena itu lembaga perwakilan ini memegang peranan yang penting dalam, menata jalannya roda pemerintahan bagi negara demokrasi modern, walaupun pada mulanya keberadaan lembaga perwakilan bukan dimaksudkan sebagai perangkat sistem demokrasi. Inilah perbedaan secara mendasar antara negara kota dengan negara bangsa dalam proses penyelenggaraan pemerintahan. Praktek demokrasi pada negara-negara kota sebagaimana telah dikemukakan di atas- tidak terdapat lembaga perwakilan, sebab demokrasi menjadi pertemuan warga kota untuk membahas masalah secara bersama-sama. Jadi, dilihat dari asal lahirnya demokrasi, penggunaan istilah demokrasi perwakilan menjadi sesuatu yang kontradiktif. ${ }^{43}$ dan lahirnya lembaga perwakilan lebih merupakan akibat dari adanya sistem feodal..$^{44}$

Meskipun demikian, keberadaan lembaga perwakilan dalam demokrasi modern adalah

${ }^{38} \mathrm{lbid} ., \mathrm{hlm}$. 7-14.

${ }^{39}$ Moh. Kusnardi dan Bintan R Saragih, op. cit., hlm. 85.

${ }^{40}$ Robert A Dahl, Perihal Demokrasi: Menjelajahi Teori dan Praktek Secara Singkat, Penerjemah A Rahman Zainuddin, Edisi Pertama, ( Jakarta: Yayasan Obor Indonesia, 2001), hlm. 16.

${ }^{41}$ Dalam situasi negara modem sekarang ini, memang beberapa persoalan masih dapat dilakukan dengan menyertakan pelibatan rakyat secara langsung sepertipemilihan presiden, referendum terhadap suatu kebijakan pemerintahan. Akan tetapi mengingat jumlah penduduk suatu negara cukup banyak dan persoalan yang semakin kompleks dihadapi dalam kehidupan bermasama suatu masyarakat, maka semua persoalan tersebut tampaknya tetap memeriukan sistem perwakilan dalam suatu negara.

${ }^{421}$ Bintan R Saragih, Lembaga Perwakilan dan Pemilihan Umum di Indonesia, Ctk. Pertama, (Jakarta: Gaya Media Pratama, Jakarta, 1988), him. 79.

${ }^{43}$ Robert A. Dahl, Perihal ...op. cit., hlm. 130.

${ }^{4}$ A.F. Pollard dalam bukunya The Evolution of Parliament sebagaimana dikutip oleh Bintan R Saragih menyatakan bahwa "Representation was not the off spring of democratic theory, but an incident of the feodal system". Lihat Bintan Saragih, loc. cit. 
sangat penting dan berarti dalam suatu negara bangsa. ${ }^{45}$ Bentuk lembaga perwakilan ini menurut John Stuart Mill merupakan pilihan bentuk pemerintahan yang ideal. Bertalian dengan sistem perwakilan dalam demokrasi modern ini John Stuart Mill lebih lanjut mengemukakan:

"But since all cannot, in a community exceeding a single small town, participate personally in any but some very minor portions of the public business it follows that the ideal type of a perfect governmentmust be representative. ${ }^{46}$

Melalui lembaga perwakilan, persoalanpersoalan yang komplek dihadapi masyarakat akan dapat diselesaikan. Dengan demikian lembaga perwakilan berfungsi untuk menjembatani dan menyalurkan aspirasi rakyat dalam proses penyelenggaraan pemerintahan. Oleh karena itu secara umum lembaga perwakilan ini mempunyai fungsi perundang-undangan (termasuk menetapkan APBN), fungsi pengawasan dan fungsi sebagai sarana pendidikan politik ${ }^{47}$ Fungsi-fungsi ini dilakukan oleh lembaga perwakilan dalam rangka mewujudkan cita-cita demokrasi modern yang dewasa ini ditkuti oleh sebagian besar negaranegara di dunia.
Penggunaan fungsi-fungsi tersebut secara teoritis mudah dipahami, tetapi dalam praktek sulit dilakukan. Kesulitan ini muncul karena lembaga perwakilan lebih menempatkan sebagaj perwakilan politik dari pada perwakilan rakyat. Padahal menurut Jimly Ashiddiqie secara teori dalam masyarakat terdapat tiga prinsip perwakilan, yaitu, political representative (perwakilan melalui partai politik), regional representative (perwakilan daerah) dan functional representative (perwakilan fungsional atau utusan golongan). ${ }^{48}$ Selain itu di masyarakat masih terdapat juga adanya "representastion in ideas" yang mungkin belum tertampung oleh representasi yang telah ada.49 Oleh karena itu apa yang diputuskan oleh lembaga perwakilan belum tentu diterima oleh masyarakat. Di sinilah kesenjangan akan muncul antara wakil yang duduk dalam lembaga perwakilan dengan rakyat yang diwakilinya. Masalah ini memunculkan persoalan mendasar di seputar keberadaan lembaga perwakilan. Artinya apakah wakil itu sebatas mewakili partai politik yang merupakan induk tempat bernaung dalam karier politiknya atau wakil itu mewakili rakyat secara keseluruhan dan melepaskan ikatan dari induk partai politiknya? Dengan kata lain,

${ }^{45}$ C.F. Strong, Modern Political Constitutions; E.L.B.S. Edition First Published, (London: The English Language Book Socjety and Sidwgwick \& Jackson Limited, , 19660, hlm. 171.

${ }^{46}$ John Stuart Mill, Utilitarianism Liberty Representative Government (London: JM Dent \& Sons Ltd., Everyman's Library, 1988), hlm. 233.

${ }^{47}$ Bintan R Saragih, op. cit., hlm. 88.

${ }^{48}$ Jimly Ashiddigie, Jawa Pos, 8 Januari 2003. Lihat pula: Pengantar Pemikiran Undang-undang Dasar Negara Kesatuan RI, The Habibie Center, Jakarta, hlm. 36. Lihat pula Jimly Ashiddiqie, Konstitusi dan Konstitusionalisme Indonesia di Masa Depan, Pusat Studi Hukum Tata Negara Fakultas Hukum Uninersitas Indonesia, Jakarta, 2002, hlm. 183- 184

49 Jimly Asshiddiqie, Konstitusi ... , Ibid., hlm. 150. 
apakah wakil itu mengambil keputusan atas dasar tuntunan nuraninya sendiri sebagai wakil rakyat atau mengambil keputusan atas dasar petunjuk garis induk partainya?

Terhadap pertanyaan-pertanyaan di atas, berbagai teori telah dikemukakan dalam mencari solusi terbaik guna membangun hubungan yang ideal antara wakil dan yang diwakilinya. Dalam melihat hubungan antara wakil dan yang diwakili ini Bintan R Saragih menemukan adanya enam macam teori yaitu: pertama, teori mandat; kedua, teori organ; ketiga, teori sosiologi Reiker; keempat, teori hukum obyektif dari Duguit; kelima, teori menurut Gilbert Abcarian; dan keenam, teori menurut A. Hoogerwer ${ }^{50}$
Meskipun telah ada enam teori tersebut dan tentunya masing-masing dengan kekuatan dan kelemahannya, namun tampaknya dalam praktek tetap saja menimbulkan masalah antara wakil dan yang diwakilinya. Artinya, apa yang dilakukan oleh wakil-wakil rakyat dalam lembaga perwakilan tidak selamanya dapat diterima oleh rakyat. Dengan kata lain praktek lembaga perwakilan ini menimbulkan suatu pertanyaan: apakah lembaga perwakilan itu bebas atau terbatas? Atas pertanyaan tersebut, persoalannya adalah apakah suatu negara demokrasi akan melaksanakan demokrasi elitis atau demokrasi partisipatoris?

${ }^{50}$ Adapun pemahaman terhadap teori-teori perwakilan tersebut adalah :pertama, teori mandat adalah teori yang melihat si wakil duduk di lembaga perwakilan karena mandat dari rakyat sehingga disebut mandataris. Dalam teori mandat dikenal adanya mandat imperatif, mandat bebas dan mandat representatif. Kedua, teori organ adalah teori yang memandang negara sebagai suatu organisme yang mempunyai alat-alat perlengkapannya seperti eksekutif, parlemen dan mempunyai rakyat yang kesemuanya mempunyal fungsi sendiri-sendiri dan saling tergantung satu sama lain. Oleh karena itu dalam kontek hubungan antara wakil dan yang diwakilinya teori ini menyatakan bahwa sesudah rakyat memilih lembaga perwakilan mereka tidak perlu lagi mencampurl lembaga pewakilan tersebut dan lembaga ini bebas berfungsi sesuai dengan wewenang yang diberikan oleh Undang-undang Dasar. Ketiga, teori sosiologi Rieker menganggap bahwa lembaga penwakilan bukan menupakan bangunan politis tetapi merupakan bangunan masyarakat (sosial). Si pemilih akan memilih wakil-wakilnya yang benar-benar ahli dalam bidang kenegaraan dan-yang akan benar-benar membela kepentingan si pemilih sehingga terbentuk lembaga perwakilan dari kepentingan-kepentingan yang ada dalam masyarakat. Keempat, teori hukum obyektif melihat bahwa dasar hubungan antara rakyat dan parlemen adalah solidaritas. Wakil rakyat dapat melaksanakan tugas-tugas kenegaraannya hanya atas nama rakyat. Sedangkan rakyat tak akan dapatmelaksanakan tugas-tugas kenegaraannya tanpa mendukung wakilnya dalam menentukan wewenang pemerintah. Keinginan untuk berkelompok yang disebut solidaritas merupakan dasar daripada hukum obyektifyang timbul. Hukum obyektif inilah yang membentuk lembaga penwakilan menjadi satu bangunan hukum dan bukan hak-hak yang diberikan kepada mandataris yang membentuk lembaga penwakilan. Kelima, Gilbert Abçarian mengemukakan adanya 4 tipe hubungan antara si wakil dengan yang diwakilinya yaitu: 1 . Si wakil bertindak sebagai "wali (trustee) ${ }^{n} ; 2$. Si wakil bertindak sebagai "utusan (delegate)" $;$ 3. Si wakil bertindak sebagai "politico"; 4. Si wakil bertindak sebagai "partisan", Keenam, A. Hoogerwer mengemukakan adanya lima model hubungan antara si wakil dengan yang mewakilinya yaitu : 1. Model delegate (utusan); 2. Model trustee (wali); 3. Model politicos; 4. Modal kesatuan; 5. Model diversivikasi (penggolongan). Lihat Bintan R Saragih, op. cit., him. 82-86. 


\section{Konsep Demokrasi Elitis}

Demokrasi elitis akan melihat bahwa rakyat sebagai orangyang tidak perlu dilibatkan dalam proses pengambilan keputusan publik, karena rakyat dianggap tidak mampu dan tidak berwenang untuk menyelesaikan persoalanpersoalan yang kompleks dalam masalahmasalah pemerintahan. Selain itu rakyat lebih baik apatis dan bijaksana untuk tidak menciptakan tindakan-tindakan yang merusak budaya, masyarakat dan kebebasan. ${ }^{51}$ Rakyat dianggap sudah cukup berperan dalam kehidupan negara melalui penyelenggaraan pemilihan umum yang dilakukan secara periodik dalam negara. Melalui pemilihan umum, rakyat sudah melakukan hak dan kewajibannya sebagai warga negara. Dalam demokrasi elitis peran rakyat digantikan oleh sekelompok elit politik dalam melaksanakan pemerintahan. Setelah dilakukannya pemilihan umum, maka proses bernegara dalam pengambilan keputusan-keputusan publik sepenuhnya diwakili oleh lembaga perwakilan. Lembaga perwakilan ini akan menjalankan tugas dan fungsinya secara bebas tanpa dibayangi oleh kontrol dan protes dari rakyatnya. Kalaupun lembaga perwakilan akan berbaik hati kepada rakyat yang menyampaikan aspirasi politik sebagai bentuk adanya partisipasi rakyat, makakata yang paling sering ditanggapi anggota lembaga perwakilan dengan satu kata adalah "ditampung" tanpa kejelasan aspirasi itu diwujudkan atau tidak. ${ }^{52}$ Di bawah sebuah pemerintahan perwakilan ini, warga negara sering menyerahkan kekuasaan yang sangat besar yang dapat digunakan sesukanya atas keputusankeputusan yang luar biasa penting. Inilah sisi gelap dari demokrasi perwakilan, walaupun diakui juga ada keuntungan-keuntungannya. ${ }^{53}$ Jadi, demokrasi elitis ini adalah demokrasi yang semu, hanya diperankan oleh sekelompok orang yang mengatasnamakan rakyat melalui justifikasi pemilihan umum.

\section{Konsep Demokrasi Partisipatoris}

Sementara itu, demokrasi partisipatoris menuntut peran aktif berbagai komponen demokrasi secara keseluruhan. ${ }^{54}$ Demokrasi jenis ini akan memberikan peluang yang luas kepada rakyat untuk berpartisipasi secara effektif dalam proses pengambilan keputusan yang menyangkut kebijakan publik. Oleh karena itu prinsip yang dipakai dalam demokrasi partisipatoris ini adalah persamaan bagi seluruh warga negara yang telah dewasa untuk ikut menentukan agenda dan melakukan

${ }^{51}$ Geoffrey de Q. Walker, Initiative and Referendum: The People's Law, (Australia: The Centre for Independent Studies, 1987), hlm. 3.

${ }^{52}$ Bimo Nugroho, Partisipasi Rakyat Membuat Undang-undang, harian Kompas 1 Agustus 2002.

${ }^{53}$ Robert A Dahl, Perihal..., op. cit., hlm. 157.

${ }^{54}$ Komponen demokrasi adalah organ-organ kelembagaan, kekuatan-kekuatan masyarakat dan kekuatankekuatan individual yang akan saling menunjang dan melengkapi dalam bejalannya sistem demokrasi yaitu : pertama, adanya pemilihan umum yang bebas untuk mengisi lembaga perwakilan; kedua, adanya responsible govemment kepada rakyat; ketiga, adanya kebebasan berserikat; keempat, adanya kebebasan mengeluarkan pendapat baik secara lisan maupun tulisan; kelima, adanya peradilan yang bebas dan tidak memihak; dan keenam, adanya pendidikan kewarganegaraan. 
kontrol terhadap pelaksanaan agenda yang telah diputuskan secara bersama. Hal ini dilakukan agar perjalanan'kehidupan bernegara mendapatkan pemahaman yang jernih pada sasaran yang tepat dalam rangka terwujudnya pemerintahan yang baik. ${ }^{55}$ Jadi, demokrasi partisipatoris padahakekatnyaadalah demokrasi yang secara sadar akan memberdayakan rakyat dalam rangka mewujudkan pemerintahan "dari rakyat, oleh rakyat dan untuk rakyat dan bersama rakyat. ${ }^{n 56}$ Adanya pemberdayaan rakyat yang akan berupa partisipasi langsung ini penting karena sistem perwakilan rakyat melalui lembaga perwakilan tidak pernah dapat diandalkan sebagai satu-satunya saluran aspirasi rakyat. Karena itulah, prinsip "representation in ideas ${ }^{n}$ dibedakan dari "representation in presence", karena perwakilan fisik saja belum tentu mencerminkan keterwakilan gagasan atau aspirasi. ${ }^{57}$

Partisipasi masyarakat dalam demokrasi partisipatoris ini menurut Samuel P Huntington dapat terjadi ketika pembangunan sosial ekonomi berhasil mencapai tingkat pemerataan yang lebih besar sehingga melahirkan stabilitas politik dan pada gilisannya memunculkan partisipasi politik yang demokratis. Partisipasi ini dapat terjadi dalam dua bentuk yaitu partisipasi mobilisasi dan partisipasi otonom. Adapun landasan sebagai pijakan dari partisipasi ini dapat berupa kelas, kelompokl komunal, lingkungan, partai dan golongan (faction). ${ }^{58}$

Akhirnya, pelibatan rakyat secara aktif dalam proses penentuan agenda, pengambilan keputusan dan kontrol terhadap kebijakan yang telah diambil secara bersama, maka rakyat akan memberikan dukungan dengan penuh antusias dan dapat merasakan bahwa mereka mempunyai tingkat "ownership" yang tinggi dalam bernegara. ${ }^{59}$ Dalam konteks ini Sherry Arntein sebagaimana dikutip oleh Bimo Nugroho mengemukakan bahwa partisipasi rakyat selaku warga negara dapat dikelompokkan menjadi dua penggolongan yaitu: pertama, partisipasiyang mengakui eksistensi rakyat untuk membuat undang-undang; dan kedua, partisipasi semu. Untuk yang pertama tingkatan partisipasi dibagi lagi dalam: (1) kontrol warga negara; (2) delegasi kewenangan; (3) kemitraan. Sedangkan untuk yang kedua dan merupakan kelanjutan yang pertama dibagi lagi dalam: (4) peredaman; (5), konsultasi; (6) informasi; (7) terapi; dan (8) manipulasi. ${ }^{60}$

${ }^{55}$ Robert A Dahl, loc.cit.

${ }^{56}$ Jimly Asshiddiqie, Konstitusi ..., op. cit., hIm. 146.

${ }^{57}$ Ibid., hlm. 168-169.

${ }^{58}$ Samuel P Huntington dan Joan Nelson, Partisipasi Politik di Negara Berkembang, ditejemahkan oleh Sahat Simamora, Cetakan Kedua, (Jakarta: Rineka Cipta, 1994), him. 9-27.

${ }^{59} \mathrm{bid}$., him. 6.

${ }^{60}$ Adapun pemahaman secara singkat terhadap delapan tingkat partisipasi tersebut adalah sbb.

(1) kontrol warga negara adalah bahwa pada tahap ini partisipasi sudah mencapai tataran di mana publik berwenang memutuskan, melaksanakan, dan mengawasi pengelolaan sumber daya; (2) delegasi kewenangan adalah bahwa di sini kewenangan masyarakat lebih besar dibanding penyelenggara negara dalam merumuskan kebijakan; (3) kemitraan adalah bahwa ada keseimbangan kekuatan relatif antara masyarakat dan pemegang 
Atas dasar pemahaman terhadap konsep demokrasi partisipatoris tersebut, maka pada dasarnya keberadaan lembaga perwakilan walaupun sangat penting dalam negara bangsa-tetaplah merupakan salah satu komponen dalam demokrasi. Artinya bahwa dinamika demokrasi modern dalam nation state - selain lembaga perwakilan yang diisi melalui pemilihan umum - masih terdapat elemen demokrasi lainnya yang mempunyai hak dan kedudukan yang sama dalam penyelenggaraan pemerintahan. Di sinilah arti pentingnya, interest group, presure group, tokoh masyarakat, pers dan partai politik ${ }^{61}$ ikut ambil bagian dalam proses penyelenggaraan pemerintahan. Peran dari elemen-elemen masyarakat ini sangat diperlukan dalam rangka menciptakan demokrasi partisipatoris.

\section{Konsep Partisipasi}

Partisipasi masyarakat dalam proses pembangunan - termasuk bidang pembentukan undang-undang ini- telah menjadi issue penting dalam konteks global dewasa ini. ${ }^{62}$ Kelahiran konsep partisipasi dalam sistem demokrasi sehingga memunculkan "participatory democracy" ini, tampaknya tidak terlepas dari adanya gerakan "New Leff" sebagai pengaruh dari "legitimation crisis" pada akhir dasawarsa 1960-an.63 Dewasa ini, gerakan dalam upaya memberdayakan masyarakat untuk turut serta dalam proses pengambilan keputusan pemerintahan telah merambah ke berbagai negara - termasuk Indonesia_yang menganut sistem demokrasi. Oleh karena itu, wacana tentang partisipasi masyarakat dalam proses pengambilan keputusan pemerintahan telah menjadi bagian tak terpisahkan dalam

kekuasaan untuk merencanakan dan mengambil keputusan bersama-sama; (4) peredaman adalah bahwa rakyat sudah mempunyai pengan h terhadap kebjjakan tetapi bila akhimya terjadi voting pengambilan keputusan, akan tampak, sejatinya kekuasaan di tangan lembaganegara, sedangkankontrol dari rakyat tidak amat menentukan; (5) konsultasi adalah bahwa rakyat didengarpendapatnyalalu disimpulkan “rakyat sudah berpartisipasi membuat undang-undang dan lembaga negara sudah memenuhi kewajiban melibatkan rakyat dalam membuat UU; (6) informasi adalah bahwa rakyat sekedar diberi tahu akan adanya UU, tidak peduli apakah rakyat memahami pemberitahuan itu, apalagi memberi pilihan guna melakukan negosiasi atas kebijakan itu: (7) terapi adalah bahwa kelompok masyarakat korban kebijakan dianjurkan mengadu ke pihak berwenang, tetapi tak jelas pengaduan itu ditindak lanjuti atau tidak; dan (8) manipulasi adalah bahwalembaga negara melakukan "pembinaan" temadap kelompok-kelompok masyarakat untuk seolah-olah berpartisipasi, padahal sejatinya adalah koptasi dan represi penguasa. Lihat Bimo Nugroho, loc. cit.

${ }^{61}$ Kekuatan-kekuatan politik ini mer.pakan kekuatan infra strukturpolitik yang perlu diberikan tempat secara proposional dalam demokrasi partisipatoris.

62 Gary Craig and Marjorie Mayo (Editor), loc. cit.

${ }^{63}$ Gerakan "New Left" yang memunculkan demokracy partisipatory ini adalah the main counter-models on the left to the legal democracy. Legal democracy bertumpu pada premis pluralist theory of politics yang mengacu kepada teori overloaded govemment, sedangkan demokrascy partisipatory bertumpu pada premis Marxist yang mengacu kepada teori legitimation cricris. Lihat David Held, Models of Democrcy, Second Edition, Polity Press, hlm. 241 dan 264. 
proses berdemokrasi di Indonesia, dan terasa lebih meningkat terutama setelah bergulimya gerakan reformasi $1998 .{ }^{64}$

Untuk memahami konsep tentang partisipasi politik secara utuh, maka pertamatama perlu diketahui terlebih dahulu pengertian dari "partisipasi". Dalam kaitan ini Samuel P Huntington dan Joan Nelson memberikan definisi tentang "partisipasi politik" adalah sbb:

"kegiatan yang dilakukan oleh para warga negara preman (warga negara biasa, pen.) dengan tujuan mempengaruhi pengambilan keputusan pemerintah. Partisipasi itu dapat secara.spontan, secara sinambung atau sporadis, secara damai atau dengan kekerasan, legal atau ilegal, efektif atau tidak efektif.. ${ }^{65}$

Dari rumusan tentang partisipasi politik tersebut, tampak bahwa substansi dari partisipasi adalah kegiatan untuk mempengaruhi keputusan pemerintah, tanpa melihat bentuk, sifat dan hasil dari partisipasi. yang dillakukannya. Meskipun demikian, dalam definisi tersebut terdapat empat hal pokok yaitu: pertama, partisipasi adalah mencakup "kegiatankegiatan", dan tidak memasukkan di dalamnya yang berupa "sikap-sikap" terhadap orientasi politik. Kedua, partisipasi adalah kegiatan politik warganegarapreman atau tepatnya peroranganperorangan dalam peranan mereka sebagai warga negara biasa. Attinya, bukan kegiatan dari orang-orang yang memang berkecimpung dalam profesi politik atau pemerintahan. Ketiga, partisipasi adalah hanya merupakan kegiatan yang dimaksudkan untuk mempengaruhi pengambilan keputusan pemerintah. Keempat, partisipasi mencakup semua kegiatan yang dimaksudkan untuk mempengaruhi pemerintah, tak peduli apakah kegiatan itu benar-benar mempunyai efek itu. ${ }^{65}$

Atas dasar. pemahaman terhadap definisi partisipasi yang di dalamnya mengandung empat hal pokok tersebut, maka pada dasarnya gerakan memberdayakan masyarakat untuk berpartisipasi dalam proses pengambilan keputusan pemerintahan ini adalah berpangka! pada adanya desirability dari masyarakat untuk mewujudkan seff-govermment dalam demokrascy partisipatory. ${ }^{67}$ Keinginan masyarakat untuk berpartisipasi dalam proses pemerintahan ini. setidaknya terdapat lima hal pokok yang menyebabkannya yaitu: pertama, modernisasi;

${ }^{64}$ Sebenamya pertama kali pemerintah mencanangkan wacana perlunya partisipasi rakyat dalam pembangunan di Indonesia telah dimulai sekitartahun 1981, akan tetapi partisipasi oleh pemerintah ketika itu dipahami sebagai kemauan rakyat untuk mendukung program-program pemerintah yang dirancang dan ditentukan tujuannya oleh pemerintah. Pemahaman partisipasi seperti ini mengasumsikan adanya subordinasi. subsistem oleh suprasistem dan bahwa subsistem adalah suatu bagian yang pasif dari sistem pembangunan nasional. Lihat Loekman Soetrisno, Menuju Masyarakat Partisipatif, Cetakan ke 6, Yogyakarta: Kanisius, 1995), hlm. 207.

${ }^{65}$ Samuel.P Huntington dan Joan Nelson, op. cit., hlm. 4. Bandingkan konsep tentang partisipasi ini dengan konsep yang dikemukakan oleh Kevin R Hardwick, Miriam Budjardjo, Ramlan Subakti, Michael Rush dan Philip Althoff dan herbert McClosky. Lihat Deden Fathurrohman dan Wawan Sobri, Pengantar IImu Politik, Edisj Pertama, (Malang: Universitas Muhammadiyah Malang, 2002), hlm. 185- 186.

${ }^{65}$ Samuel P Huntington dan Joan Nelson, op. cit, hlm. 6-8.

${ }^{67}$ William N. Nelson, On Justifying Democracy, (London: Routledge \& Kegan Paul Ltd., 1980), hIm. 51. 
kedua, perubahan-perubahan struktur kelas sosial; ketiga, pengaruh kaum intelektual dan komunikasi massa modern; keempat, konflik di antara kelompok-kelompok pemimpin politik; dan kelima, keterlibatan pemerintah yang meluas dalam urusan sosial, ekonomi dan kebudayaan. ${ }^{68}$

Adanya berbagai penyebab dari keterlibatan masyarakatuntukmenyalurkan desirability dalam penyelenggaraan pemerintahan tersebut, berangkat dari suatu asumsi bahwa yang mendasari demokrasi (dan partisipasi) adalah dirinya sendiri yang paling tahu tentang apa yang baik bagi dirinya. ${ }^{99}$ Atas dasar asumsi inilah rakyat melakukan partisipasi yang dilakukan dalam berbagai bentuk-bentuk partisipasi polibk yang dapat berupa konvensional maupun non konvensional. Partisipasi politik yang konvensional adalah: pemberian suara (voting), diskusi politik, kegiatan kampanye, membentuk dan bergabung dalam kelompok kepentingan, komunikasi individual dengan pejabat politik dan administratif. Sedangkan partisipasi politik yang non konvensional adalah pengajuan petisi, berdemontrasi, konfrontasi, mogok, tindak kekerasan politik terhadap harta benda, tindakan kekerasan politik terhadap manusia maupun perang gerilya dan revolusi..$^{70}$
Dengan adanya bentuk partisipasi konvensional maupun yang non konvensional tersebut, masalah lebih lanjut adalah mengapa seseorang berpartisipasi atau kurang berpartisipasi dalam proses politik? Dalam kaitan ini terdapat faktor-faktor yang diperkirakan mempengaruhi tinggi rendahnya partisipasi seseorang yaitu kesadaran politik dan kepercayaan kepada pemerintah (sistem politik). ${ }^{71}$ Oleh karena adanya faktor-faktor yang dapat mempengaruhi tinggi atau rendahnya partisipasi seseorang dalam melihat suatu persoalan dalam lingkungannya, maka ditemukan adanya empat tipe partisipasi yaitu: pertama, apabila seseorang memiliki kesadaran politik dan kepercayaan kepada pemerintah yang tinggi, maka partisipasi politik cenderung aktif; kedua, apabila seseorang tingkat kesadaran politik dan kepercayaan kepada pemerintah rendah, maka partisipasi politik cenderung pasif-tertekan (apatis); ketiga, apabila kesadaran politik tinggi tetapi kepercayaan kepada pemerintah sangat rendah, maka akan melahirkan militan radikal; dan keempat, apabila kesadaran politik sangat rendah tetapi kepercayaan kepada pemerintah sangat tinggi, maka akan melahirkan partisipasi yang tidak aktif (pasif). ${ }^{72}$

${ }^{68}$ Gabriel AAlmond, Sosialisasi, Kebudayaan dan Partisipasi Politik, diedit oleh Mochtar Mas'oed dan Collin Mac Andrews dalam Perbandingan Sistem Politik, Cetakan Keenambelas, (Yogyakarta: Gajah Mada University Press, 2001), hlm. 45-46.

${ }^{69}$ Peter L Barger sebagaimana dikutip oleh Ramlan Surbakti, Memahami llmu Politik, Cetakan Keempat, (Jakarta: Grasindo, 1999), hlm. 140.

${ }^{70}$ Mochtar Mas'oed dan Colin McAndrews (Editor), op. cit, hlm. 47.

${ }^{71}$ Yang dimaksud dengan kesadaran politik adalah kesadaran akan hak dan kewajiban sebagai warga negara yang dapat berupa pengetahuan seseorang tentang lingkungan masyarakat dan politik, serta minat dan perhatian seseorang terhadap lingkungan masyarakat dan politik tempat diahidup. Sedangkan yang dimaksud dengan sikap dan kepercayaan kepada pemerintah ialah penilajan sseorang terhadap pemerintah: apakah ia menilai pemerintah dapat dipercaya dan dapat dipengaruhi atau tidak. Lihat Ramlan Surbakti, op. cit, hlm. 144.

72 Jeffry M Paige sebagaimana dikutip oleh Ramlan Surbakti, Ibid. 
Dengan melihat pada uraian tentang berbagai hal yang bertalian dengan partisipasi di atas, maka problematika partisipasi dalam kehidupan berdemokrasi menjadi suatu persoalan yang debatable. Artinya, tuntutan adanya partisipasi dalam sutu negara demokrasi pada satu sisi tampak merupakan suatu keniscayaan, namun di sisi yang lain dipertanyaakan pula apakah partisipasi itu dapat dilakukan dalam kerangka kebebasan dan persamaan warga negara dalam penyelenggaraan suatu negara? Oleh karena itu, permasalahannya adalah apakah pemerintahan yang demokratis itu tergantung pada ada tidaknya partisipasi dari masyarakat dalam membuat keputusan pemerintahan? Jika adanya partisipasi ini menjadi suatu ukuran dalam proses pengambilan keputusan yang demokratis, maka ukuran apakah yang dapat untuk menentukan bahwa suatu partisipasi masyarakat itu merupakan keinginan bersamà dalam masyarakat? Permasalahan ini tentu tidak mudah untuk menjawab, sebab pada hakekatnya partisipasi ini akan sampai pada persoalan nilai-nilai yang bertalian dengan morality suatu masyatakat. Oleh karena itu ketika permasalahan partisipasi pada gilirannya akan bermuara pada permasalahan moral, sudah barang tentu akan sulit untuk menentukan nilai-nilai moral dari masyarakat yang ukurannya bisa berbedabeda. Dalam konteks ini, Joan Nelson mengemukakan bahwa "the participation theorist have failed to provide us with such a theory, and their arguments therefore radically incomplete. ${ }^{73} \mathrm{Jadi}$, partisipasi sebagai suatu intrumen demokrasi yang sangat diharapkan dalam membangun self-government bagi suatu negara demokrasi, ternyata tidak dapat bekerja secara utuh sebagai suatu teori dan telah gagal dalam membangun argumenargumennya secara fundamental. Dengan demikian, bekerjanya institusi-institusi demokrasi seperti partai politik lembaga perwakilan dan pemerintahan yang bertanggung-jawab, pendeknya demokrasi prosedural, tampaknya akan lebih baik sebagai penyelenggara pemerintahan sepanjang mereka bekerja atas dasar penyerapan nilai-nilai moral yang baik di masyarakat.

\section{Konsep Elitis dan Partisipatoris dalam Konteks Pembentukan Undang- undang}

Bertolak dari uraian tentang konsep demokrasi, demokrasi elitis, demokrasi partisipatoris dan partisipasi di atas, maka dalam demokrasi elitis maupun demokrasi partisipatoris akan melahirkan problematik yang menarik ketika dihubungkan dengan pembentukan undang-undang. Keduanya mempunyai kekuatan dan kelemahan masingmasing. Memang pada demokrasi elitis proses pembentukan undang-undang akan lebih mudah dibuat dari pada proses pembentukan undang-undang pada demokrasi partisipatoris. Masalahnya adalah undang-undang yang dibuat itu tidak berada dalam ruang yang hampa, tetapi berada dalam dinamika kehidupan masyarakat luas dengan segala kompleksitasnya. Artinya, masyarakat yang akan dituju oleh suatu undang-undang menghadapi berbagai keterbatasanketerbatasan dalam menerima kehadiran

\footnotetext{
${ }^{73}$ lbid., hlm. 52.
} 
suatu undang-undang. ${ }^{74}$ Dengan demikian, maka suatu undang-undang yang dibuat secara sepihak oleh fihak legislator, sangat mungkin kehadirannya akan ditolak karena tidak sesuai dengan rasa keadilan dalam masyarakat. Oleh karena itu, disinilah arti pentingnya peran serta masyarakat dilibatkan dalam proses pembentukan undang-undang. Dengan kata lain demokrasi partisipatoris diharapkan lebih menjamin bagi terwujudnya ketertiban dan keadilan, karena masyarakat merasa ikut membuat dan memiliki lahirnya suatu undang-undang. Adanya partisipasi politik dalam pembentukan undang-undang ini juga akan menjadikan masyarakat lebih bermakna dan pemerintah lebih tanggap dalam proses demokrasi, sehingga melahirkan pemerintahan yang bermoral dan warga negara yang bertanggung jawab dalam masyarakat. ${ }^{75}$

Meskipun demokrasi partisipatoris merupakan pilihan terbaik dalam proses pembentukan undang-undang, akan tetapi dalam implementasinya dapat menimbulkan permasalahan yang tak dapat dielakkan. Artinya, sampai di mana batas partisipasi publik dapat diterima dalam proses pembentukan undang-undang? Permasalahan ini muncul, mengingat secara konstitusional kewenangan pembentuk undang-undang dilakukan oleh lembaga legislatif. Dengan kata lain, apakah ketika partisipasi publik berjalan secara luas berarti lebih demokratis dalam pembentukan undang-undang? Apakah dengan partisipasi publik yang luas tidak berakibat pada gagalnya pembentukan suatu undang-undang, mengingat semakin banyaknya aspirasi yang harus diterima dalam pembentukan undangundang?

Jawaban terhadap berbagai permasalahan tersebut tidaklah sederhana. Pada dasarnya problematika di atas telah menyangkut persoalan definisi dan ukuran demokrasi. Artinya, pengertian dan ukuran demokrasi itu dapat dilihat dari berbagai sudut pandang. Dalam kaitan ini Sartory dan Schumpeter sebagaimana dikutip oleh Geraint Parry dan George Moyser mengemukakan bahwa perlu adanya pembagian tugas secara professional antara rakyat dengan politisi. Oleh karena itu pemisahan partisipasi dari pemungutan suara adalah tidak merupakan kunci indikator dari demokrasi. Kesadaran wakil atau elit politik akan menjadi jauh lebih penting. ${ }^{76}$ Akan tetapi sebagaimana telah dikemukakan di muka, adanya lembaga perwakilan ini barulah mewakili masyarakat dari aspek political representative. Selain itu di masyarakat masih terdapat functional representatitive, regional representative dan idea representative. ${ }^{77} \mathrm{Jadi}$, meskipun telah dilakukan pembagian yang professional antara rakyat dengan politisi yang pada gilirannya bermuara pada pentingnya kesadaran lembaga perwakilan, namun rakyat tetap harus diberikan tempat untuk bisa berpartisipasi secara aktif dalam proses

${ }^{74}$ Ann Seidmann at all, Legislative Drafting for Democratic Social Change: A Manual for Drafters, First Published, (London The Hague Boston: Kluwer Law Intemational Ltd., 2001), hlm. 15

${ }^{75}$ Samuel PHuntington, Partisipasi..., op. cit., hlm. 25.

${ }^{76}$ David Beetham (Editor), Defining and Measuring Democracy, First Published, (London-Thousand Oaks -New Delhi: Sage Publications, 1994), hlm. 46.

$n$ Jimly Asshiddiqie, Jawa Pos ... loc. cit. 
pembentukan undang-undang. Partisipas! rakyat yang tercermin dalam berbagal kelompokkelompok masyarakat ini dapat dilakukan melalui, misalnya: inisiatif rakyat, public hөaring, unjuk rasa, modia massa, tanggapan terhadap draf RUU, penyampaian terhadap kajian-kajian naskah akademik, penolakan terhadap RUU yang telah ditetapkan sebagai UU, referendum dsb. Masalahnya adalah bagaimana partisipasi masyarakat dalam proses pembentukan undang-undang ini tidak menjadi kondisi yang anarkhis. Oleh karena itu partisipasi masyarakat dalam pembentukan undang-undang dalam suatu negara demokrasi ini perlu dituangkan secara proporsional dalam suatu aturan hukum. Maka, uraian berikutnya akan melihat tentang konsep negara hukum, konstitusi dan undang-undang.

\section{Konsep Pembentukan Undang-undang yang Partisipatif}

Pengaturan kekuasaan legislatif dalam UUD ' 1945 ini ternyata telah mengalami pergeseran ,seiring dengan dinamika perkembangan ketatanegaraan di Indonesia. Melihat pada berbagai ketentuan pasal-pasal tersebut, maka tampak sekali bahwa pemegang kekuasaan dalam membentuk undang-undang menurut UUD 1945 telah bergeser dari Presiden kepada DPR. Ini berarti bahwa kewenangan membentuk undang-undang ada pada DPR, sedangkan kewenangan untuk memberikan persetujuannya ada pada Presiden.

Pergeseran penekanan kekuasaan legislatif tersebut tampaknya dimaksudkan untuk lebih memberdayakan DPR dalam proses pembentukan undang-undang. Dalam konteks yang lebih luas pergeseran penekanan kekuasaan legislatif darl Presiden kepada DPR ini bermakna untuk memberdayakan rakyat dalam proses pembentukan undang-undang. Artinya rakyatyang pada akhirnya akan terkena pemberlakuan undang-undang perlu dilibatkan sejak awal penyusunan undang-undang. Rakyat tidak lagi hanya sebagal obyek dari pembentukan undang-undang, tetapi rakyat ditempatkan sebagai subyek dan sekaligus obyek dari pembentukan undang-undang. Dengan pelibatan rakyat dalam proses pembentukan undang-undang ini, pada gilirannya diharapkan akan melahirkan undang-undang yang demokratis dan diterima rakyat secara wajar tanpa paksaan bahkan spontan. Oleh karena itu tuntutan partisipasi rakyat yang tercermin dalam kelompokkelompok masyarakat seperti perwakilanperwakilan fungsional, perwakilan-perwakilan teritorial, kelompok-kelompok penekan, kelompok-kelompok kepentingan, tokoh-tokoh intelektual, tokoh-tokoh masyarakat dan sebagainya, kiranya perlu mendapatkan tempat secara proporsional dalam proses pembentukan undang-undang. Dengan demikian rakyallah yang menjadi sumber dan sekaligus pembuat undang-undang untuk mengatur diri mereka sendiri dan pemerintahannya. Jadi, semua undang-undang pada dasarnya harus dibentuk secara demokratik. ${ }^{78}$ Dengan kata lain undangundang harus responsif sesuai dengan dinamika kehidupan masyarakat Melalui undang-undang yang responsif ini, diharapkan perumusan yang bertalian dengan legal right, privelege, function, duty, status or disposition ${ }^{79}$ yang akan

\footnotetext{
${ }^{78}$ Bagir Manan, loc. cit.

${ }^{79}$ Reed Dickerson, The Fundamental of Legal Drafting, Second Edition, Little Brown and Company, Canada, 1986, hlm. 3.
} 
menjadi muatan dari undang-undang akan mendekati rasa keadilan masyarakat yang sebenarnya. Sebab, meskipun Hans Kelsen dengan teori hukum murninya menolak dengan tegas pencampuran antara hukum dan keadilan, ${ }^{80}$ tetapi John Rowls meletakkan adanya dua prinsip keadilan sebagai dasar dari struktur masyarakat yaitu:

1. Each person is to have an equal right to the most extensive basic liberty compatible with similar liberty for others;

2. Social and economic inequalities are to be arranged so that they are both:

a. Reasonably expected to be to everyone's advantage, and

b. Attached to positions and offices open to all. ${ }^{81}$

Atas dasar dua prinsip dasar keadilan yang diletakkan oleh John Rowls tersebut, maka tidak dapat dielakkan bahwa hukum - - termasuk undang-undang - harus mencerminkan keadilan dalam masyarakat. Dengan kata lain sebagaimana dikemukakan oleh Jeremy Bentham dalam memandang hukum dengan prinsip filosofi utilitarianismenya menyatakan "the greatest happiness of the greatest number of people, ${ }^{\text {"82 }}$ maka pemibentuk undangundang harus memperhatikan "the public good ought to be the object of the legislator. ${ }^{83}$
Lebih lanjut Bentham menegaskan bahwa legislation adalah

"a branch of morals being the principles upon which men's actions were to be directed to the greatest quantity of possible happiness ${ }^{\mathrm{g} 84}$

Hal ini hanya akan terwujud jika masyarakatyang akan terkena obyek dari suatu undang-undang dilibatkan dalam proses pembentukannya. Pelibatan masyarakat dalam pembentukan undang-undang menuju hukum yang responsif ini hanya akan terwujud dalam masyarakat. yang demokratis. Pada akhirnya masyarakat yang demokratis ini akan terwujud ketika sistem politiknya adalah tatanan politik yang demokratis. ${ }^{85} \mathrm{O}$

\section{Daftar Pustaka}

\section{A. Pustaka Umum}

Abdurrahman, IImu Hukum, Teori Hukum dan IImu Perundang-undangan, Cetakan I, Bandung: Citra Aditya Bakti, 1985.

Asshiddiqie, Jimly, Gagasan Kedaulatan Rakyat Dalam Konstitusi dan Pelaksanaannya di Indonesia, Cetakan Pertama, Jakarta: Ikhtiar Baru van Hoeve, 1994.

${ }^{80}$ Hans Kelsen, What is Justice? Justice, Law, and Politics in The Mirror of Science, (London, England: Cambridge University Press, 1957), hlm. 301-302. Lihat pula Hans Kelsen, General.. op. cit., hlm. 5.

${ }^{81}$ John Rowls, A Theory of Justice, First Published, (London: Oxford University Press, 1976), hlm. 60-65.

${ }^{2}$ Hari Chand, Modern Jurisprudence, (Kuala Lumpur. International Law Book Services, 1994), hlm. 67.

s Jeremy Bentham, The Theory of Legislation, (India: Bombay N.M. Tripathi Private Limited, 1979), hlm. 1.

${ }^{84}$ Hari Chand, op. cit, hlm. 69 . -

${ }^{85}$ Moh Mahfud MD, loc. cit. 
- Pengantar Pemikiran Undang-undang Dasar Negara Kesatuan RI, Jakarta: The Habibie Center, 2001.

Konstitusi dan Konstitusionalisme Indonesia di Masa Depạn, Jakarta: Pusat Studi Hukum Tata Negara Fakultas Hukum UI, 2002.

Attamimi, A Hamid, Teori Perundangundangan Indonesia, Suatu Sisi IImu Pengetahuan Perundang-undangan Indonesia yang Menjelaskan dan Menjernihkan Pemahaman, Pidato Pengukuhan Jabatan Guru Besar Tetap Fakultas Hukum UI, Jakarta, 1992.

Azhari, Muhammad Thahir, Negara Hukum, Suatu Studi Tentang Prinsip-prinsipnya Dilihat dari Segi Hukum Islam, Implementasinya pada Periode Negara Madinah dan Masa Kini, Cetakan Pertama, Bulan Bintang; Jakarta, 1992.

Beetham, David (Editor), Defining and Measuring Democracy, London -Thousand Oaks -New Delhi: First Published, Sage Publications, 1994.

Bentham, Jeremy, The Theory of Legislation, Bombay N.M. Tripathi Private Limited, India, Ashgate Publishing Limited, England, 1979.

Budiardjo, Miriam, Dasar-dasar IImu Politik, Cetakan VIII, Jakarta: Gramedia, 1983.

Chand, Hari, Modern Jurisprudence, Kuala Lumpur: International Law Book Services, 1994.

Craig, Gary and Marjorie Mayo (Editor), Community Empowerment A Reader in Par- ticipation and Development, London \& New Jersy: Zed Books Ltd, 1995.

Dahl, Robert A, Democracy, USA: Yale University Press, 1998,

Demokrasi dan Para Pengkritiknya, Jilid II, Diterjemahkan oleh A Rahman Zainuddin, Edisi Pertama, Jakarta: Yayasan Obor Indonesia, 1992.

- Perihal Demokrasi : Menjelajahi Teori dan Praktek Secara Singkat, Penerjemah A Rachman Zainuddin, Edisi Pertama, Jakarta: Yayasan Obor Indonesia, 2001.

Dickerson, Reed, The Fundamental of Legal Drafting, Second Edition, Canada: Little, Brown and Company, 1986.

Friedman, M. Lawrence, The Legal System, A Social Science Perspective, New York: Russel Sage Foundation, 1975.

Gaffar, Firoz dan Ifdal Kasim (Penyunting). Reformasi Hukum di Indonesia, Penerjemah Niar Reksodipuro \& Imam Pambagyo, Cetakan Kedua, Jakarta: Siber Konsultan, 1999.

Huntington, Samuel $P$, Gelombang Demokratisasi Ketiga, Penerjemah Asril Marjohan, Ctk. Kedua, Jakarta: Pustaka Utama Grafitri, 1995.

Ingman, Terence, The English Legal Process, London: Blackstone Press Limited, 1983.

Joeniarto, Selayang Pandang Tentang Sumber-sumber Hukum Tata Negara di Indonesia, Cetakan IV, Yogyakarta; Liberty, 1983. 
Kelsen, Hans, General Theory of Law and State, translated by Anders Wedberg, Russel \& Russel, New York, 1961.

Koesnardi, Moh. dan Bintan R Saragih, IImu Negara, Cetakan Ketiga, Jakarta: Gaya Media Pratama, 1995.

Manan, Bagir, Dasar-dasar Konstitusional Peraturan Perundang-undangan Nasional, disajikan dalam pendidikan singkat "Kajian Perundang-undangan" untuk para pengajar Fakultas Hukum se Sumatera, yang diselenggarakan oleh Fakultas Hukum Universitas Andalas, tanggal 11 - 18. Oktober 1993.

Mas'oed, Mohtar (Editor), Perbandingan Sistem Politik, Cetakan Keenambelas, Yogyakarta:Gajah Mada University Press, 2001.

Moh. Mahfud MD, Politik Hukum di Indonesia: Pengaruh Konfigurasi Politik Terhadap Produk Hukum, Jakarta: LP3ES, 1995.

Nelson, William N, On Justifying Democracy, First Published, Routledge \& Kegan Paul Lid., London, 1980.

Patfield, Fiona and Robin White, The Changing Law, Liecester University Press, Liecester, London and New York, 1990.

Rahardjo, Satjipto, "Penyusunan Undangundang Yang Demokratis," makalah seminar Mencari Model Ideal Penyusunan Undang-undang Yang Demokratis dan Konggres Asosiasi Sosiologi Hukum Indonesia, Fakultas Hukum , Undip, Semarang, tanggal 15 - 16 April 1998.

Rawls, John, A Theory of Justice, First Pub- lished, London: Oxford University Press, 1976.

Saragih, Bintan R, Lembaga Perwakilan dan Pemilihan Umum di Indonesia, Cetakan Pertama, Gaya Media Pratama, Jakarta, 1988.

Seidmen, Robert, B. , Ann Seidmen and Nalin Abeysekere, Legislative Drafting for Demokratic Social Change: A Manual for Drafters, First Published, London: Kluwer Law International, 2001.

Soejito, Irawan, Teknik Membuat Undangundang, Cetakan Kelima, Jakarta: Pradnya Paramita, 1993.

Supadjar, Damardjati, Mencari Model Penyusunan Undang-undang Yang Demokratis, Seminar "Mencari Model Ideal Penyusunan Undang-undang Yang Demokratis dan Konggres Asosiasi Sosiologi Hukum Indonesia", Fakultas Hukum, Undip, Semarang, tanggal 15 - 16 April 1998.

Surbakti, Ramlan, Memahami Ilmu Politik, Cetakan Keempat, Jakarta: GramediaWidiasarana Indonesia, 1999.

Strong, C.F., Modern Political Constitutions, E.L.B.S. Edition First Published, London: The English Language Book Society and Sidwgwick \& Jackson Limited, 1966.

Tomasic, Roman (Editor), Legislation and Society in Australia, Australia: The Law Foundation of New South Wales, 1979.

Waiker, Geoffrey de Q, Initiative and Referendum: The People's Law, Australia; The 
Centre for Independent Studies, 1987. Warren, Harris G, at all, 'Our Democracy at Work, USA: Printice Hall, Inc., Englewood Cliffs, 1963.

Widjaja, Rosjidi Rangga, Pengantar IImu Perundang-undangan Indonesia, Cetakan I, Bandung: Mandar Maju, 1998.

Wheare, K.C., Modern Constitutions, Third Impression, New York: Oxford University Press, 1975.

\section{B. Aturan Dasar dan Peraturan Perundang-undangan}

Undang-undang Dasar 1945 beserta Amandemennya

Undang-undang No. 5 Tahun 1974 tentang Pokok-pokok Pemerintahan di Daerah Undang-undang No. 3 Tahun 1985 tentang
Partai Politik dan Golongan Karya

Undang-undang No. 5 Tahun 1985 tentang Referendum

Undang-undang No. 14 Tahun 1992 tentang Lalu Lintas dan Angkutan Jalan Raya

Undang-undang No. 4 Tahun 1995 tentang Pemilihan Umum

Undang-undang №. 5 Tahun 1995 tentang Susunan dan Kedudukan MPR, DPR dan DPRD

Rancangan Undang-undang tentang Penanggulangan Keadaan Bahaya

Keputusan DPR No. 16/DPR RI///1999-2000 tentang Peraturan Tata Tertib DPR RI

Keputusan Presiden No. 188 Tahun 1998 tentang Tata Cara Pembentukan Undang-undang dan Peraturan Pemerintah

Intruksi Presiden No. 15 Tahun 1975 tentang Tata Cara Mempersiapkan RUU dan Rancangan Peraturan Pemerintah

\&OOE 